\title{
Mothers of children with autistic disorder: perceptions and trajectories ${ }^{a}$
}

\author{
Mães de crianças com transtorno autístico: percepções e trajetórias
}

Madres de niños con trastorno autista: percepciones y trayectorias

\author{
Michele Ebert ${ }^{\mathrm{b}}$ \\ Elisiane Lorenzinic \\ Eveline Franco da Silva ${ }^{d}$
}

DOl: $\quad$ http://dx.doi.org/10.1590/19831447.2015.01.43623

\footnotetext{
article based on Final Course Work of the Nursing Programme: Trajectories of mothers of children with autistic disorder.

${ }^{b}$ Nurse with a degree from the Faculdade Nossa Senhora de Fátima (FÁTIMA), Nurse of the Neonata Intensive Care Unit of the Virvi Ramos Hospital, Caxias do Sul (RS), Brazil.

' Nurse, Specialist in Nursing Management, Master's degree in Health Sciences, Doctoral degree student of Nursing at the Universidade Federal do Rio Grande do Sul (UFRGS), Porto Alegre (RS), Brazil.

${ }^{d}$ Nurse, Specialist in Obstetrics Nursing and Public Health with emphasis on Family Health, Master's degree in Nursing from the UFRGS, Faculty member at the Faculdade FÁTIMA and Faculdade da Serra Gaúcha (FSG), Caxias do Sul (RS), Brazil.
}

\begin{abstract}
Childhood autism is characterized by severe and global impairment in several areas of human development and demands extensive care and dependence on the parents. The objective of this study was to understand the perceptions of mothers of children with autism regarding changes suffered by the child and their trajectories in search of an autism diagnosis. This is an exploratory descriptive study with a qualitative approach conducted with ten participant mothers. Data were collected in 2013 by means of semi-structured interviews. Thematic content analysis produced the following categories: perceptions of mothers as to changes in behaviour and/or development of their children; and trajectories of mothers in search of a diagnosis for their children. After the perception of changes in behaviour/development, mothers face an arduous trajectory of healthcare service utilization.
\end{abstract}

Keywords: Autistic disorder. Child health. Mental health. Child development. Paediatric nursing.

\section{RESUMO}

0 autismo infantil caracteriza-se por comprometimento grave e global em diversas áreas do desenvolvimento humano, o que gera ampla demanda de cuidados e dependência dos pais. Objetivou-se conhecer as percepções de mães de crianças com autismo quanto às alterações apresentadas pelo filho e às suas trajetórias percorridas na busca pelo diagnóstico de autismo. Trata-se de um estudo exploratório, descritivo, com abordagem qualitativa, do qual participaram dez mães. A coleta de dados ocorreu em 2013, com entrevistas semiestruturadas. Da análise de conteúdo temática emergiram as categorias: percepções de mães quanto a alterações no comportamento e/ou desenvolvimento de seus filhos; e trajetórias das mães na busca pelo diagnóstico do filho. Após a percepção das alterações no comportamento/desenvolvimento, as mães enfrentam uma peregrinação pelos serviços de saúde.

Palavras-chave: Transtorno autístico. Saúde da criança. Saúde mental. Desenvolvimento infantil. Enfermagem pediátrica.

\section{RESUMEN}

El autismo infantil se caracteriza por comprometimiento grave y general en distintas áreas del desarrollo humano, lo que genera amplia demanda de cuidados y dependencia de los padres. Se objetiva conocer las percepciones de madres de niños con autismo con relación a las alteraciones presentadas por el hijo y las trayectorias efectuadas en la búsqueda por el diagnóstico de autismo. Se trata de un estudio exploratorio descriptivo de abordaje cualitativo, que involucró a diez madres. La recolección de datos ocurrió en 2013, con entrevistas semiestructuradas. Del análisis de contenido temático surgieron las categorías: percepciones de las madres como a los cambios en el comportamiento y/o el desarrollo de sus hijos; y trayectorias de las madres en búsqueda de diagnóstico del niño. Después de la percepción de los cambios en el comportamiento/desarrollo, las madres se enfrentan a una peregrinación a los servicios de salud.

Palabras clave: Trastorno austíitico. Salud del niño. Salud mental. Desarrollo infantil. Enfermería pediátrica. 


\section{DINTRODUCTION}

Since the last decade, the federal government has been investing on children's mental healthcare. In the Brazilian Unified Health System (SUS), assistance for this population seeks to effectively replace the former asylum-based model for a territorial and community-based care system. Moreover, the network of children's psychosocial care centres, called Centros de Atenção Psicossocial Infantil (CAPSi), a daily public assistance service for children and adolescents with mental disorders, has been expanded. This assistance modality stimulates social and family integration and helps children and adolescents establish their autonomy ${ }^{(1)}$.

In Brazil, despite the lack of official statistics, an estimated $10 \%$ to $20 \%$ children and adolescents suffer from mental disorders, and $3 \%$ to $4 \%$ of these disorders require intensive treatment. Autism spectrum disorder, also known as autism, is one of the more frequent ailments in infancy ${ }^{(2)}$. This disorder is defined by the presence of symptoms that start in infancy, typically perceived before the age of three, that compromise the individuals capacity to perform daily functions. These symptoms are recognized as social and communication deficits and fixed and repetitive behaviour ${ }^{(3)}$.

Global developmental delay and intellectual deficiency are common complaints during neurological consultations, but the confirmation of childhood autism diagnosis is difficult to establish in comparison to other etiologies that are common to these complaints ${ }^{(4)}$. Diagnosis is also complex in relation to eligibility for services. Recently, the taxonomy of diagnoses of the American Psychiatric Association was revised and the topic is still under discussion in the scientific community ${ }^{(5)}$.

Children with autism have major difficulties in performing common tasks that are appropriate for their developmental stage. This creates dependence on parents and family members, and interferences in intrafamily relationships and in relationships with other members of society ${ }^{(6)}$. The families of these children, in turn, face the challenge of adjusting their plans and future expectations to these limitations, and must adapt and make constant changes in their daily routines to meet the needs of the child. Surprisingly, in Brazil, there are few studies that show how the therapeutic search process occurs, which is when the mothers of children with autism select, evaluate and adhere to given form of treatment ${ }^{(7-8)}$. This scarcity creates a gap in the provision of children's mental healthcare, considering that the particularities confronted by the mothers and family members of children with autism remain unknown, which can hinder planned care that targets the demands and needs of these children and their families.
The experiences of the main author, as a nursing intern student of the Child and Adolescent Health Nursing course at a children's psychiatry hospital unit and a Basic Health Unit (UBS), allows scientific proximity to this subject. Also, being the mother of an autistic child served as motivation for conducting this study. In view of these considerations, the following guiding research question was created: What are the perceptions and trajectories of mothers of children with autism? To answer this question, the object of this study was to understand the perceptions of mothers of children with autism in relation to the changes presented by the child and the trajectories in search of an autism diagnosis.

\section{METHOD}

This is a descriptive, exploratory study with a qualitative approach. This type of approach was selected due to its flexibility in terms of providing an understanding of the whole, a deep involvement of researchers with the field and its emphasis on subjectivity ${ }^{(9)}$. Furthermore, exploratory studies seek to investigate situations in which there is little accumulated knowledge, which is the case of the perceptions and trajectories of mothers of children with autism.

The investigation was conducted at the Mosaico Centro Dia, a medium complexity programme of the Fundação de Assistência Social (FAS), a social services foundation in a municipality in the northeast of the state of Rio Grande do Sul, Brazil. This programme offers assistance to children, adolescents and adults with global developmental delay and attends an average of 30 children with autism a month.

A total of ten mothers of children with autism who attend the FAS programme participated in the study. The programme coordinator was initially contacted by phone to schedule a research presentation and meet possible participants. Subsequently, the head researcher invited the mothers to participate in the study. These participants included mothers of children with autism under 11 years and 11 months of age, based on the Statute of Children and Adolescents, that establishes that children are individuals under the age of 12. Moreover, the current diagnostic process for children is different to the process for adults due to greater advancements in the clarification of the characteristics of autism in adults ${ }^{(8,10)}$. Criterion for exclusion considered whether the child had other associated neurological diseases detected since the neonatal period.

To determine the number of participants, the data saturation criterion was adopted, that is, data collection is interrupted when the obtained information becomes repetitive ${ }^{(11)}$. 
Data were collected from March to April 2013 by means of individual semi-structured interviews based on a script, created by the authors, containing the following questions: Can you tell us about your trajectory since the first signs of changes in behaviour and/or development perceived in your child? What were the main changes in behaviour and/or development in your child that were observed by healthcare professionals? Did the nurse participate in the assessment of your child's behaviour and/or development? How? Interviews were previously scheduled, with an average duration of 50 minutes, and conducted in a room at the Mosaico Centro Dia especially provided for the interviewer of this study. To fully benefit from the obtained data, interviews were audio recorded and transcribed in Microsoft Word 2007 ${ }^{\text {TM }}$ documents for later analysis.

Data analysis was based on thematic content analysis according to the stages of pre-analysis, material exploration, treatment of results, inference and interpretation ${ }^{(12)}$. This process led to two thematic categories: one was related to the perceptions of mothers on changes in their children, and another was related to the their trajectories in search of a diagnosis.

This study observed the orientations of Resolution $466 / 2012^{(13)}$, and was only initiated after being authorized by the FAS and the Mosaico Centro Dia and approved by the Research Ethics Committee of the Associação Cultural e Científica Virvi Ramos, with Ethical Appreciation Certificate (CAAE): 11558813.1.0000.5523. All participants received detailed information on the study and signed an informed consent statement. The participant's names were represented using the letter $\mathrm{M}$, for mother, followed by a number according to the chronological order of the interviews (M1, M2, .., M10).

\section{RESULTS AND DISCUSSION}

During characterization of the participants, it was verified that the mothers were between the ages of 27 and 47 and their children were between 4 and 11 years old. Five mothers had not completed primary schooling, two had finished primary school, two had completed secondary school and one had a university degree and was finishing her post-graduate studies. In terms of marital status, most mothers (seven) were married with the father of their children. Only one of the participants stated she used supplementary healthcare services. Prior to obtaining assistance for their children at the Mosaico Centro Dia, these mothers only used services offered by the UBS of the municipality, including puericulture consultations with a paediatrician and a nurse.
The characterization of participants of this study was similar to that of a study on the mothers of children with special needs ${ }^{(14)}$ and therapeutic itineraries of mothers of children with autism ${ }^{(8)}$.

The information analysis process produced the following categories: perceptions of mothers in relation to changes in the behaviour and/or development of their children; the trajectories of these mothers when searching for a diagnosis for their children.

\section{Perceptions of mothers in terms of behavioural/ developmental changes in their children}

Delayed speech and language, difficulties or lack of interaction with children in the child's environment and lack of interest in play were mentioned by all participants at different moments during the interviews.

In general, mothers are the first persons to perceive changes in the behaviour and/or development of their children and these alterations are perceived since the first months of the child's life ${ }^{(8)}$. One participant, however, stated she did not perceive changes in her daughter before she was two years old and another stated she only perceived that her son's behaviour was different to that of other children when he started going to preschool, although the child showed the typical alterations of autism:

I did not notice anything until she was two. My husband had already realized [...] that she had some difficulties, but I did not notice anything (M5).

I only realized something was different when he started preschool. On the first day that the head mistress called me and asked if I had ever heard of autism, he was four years old, [...] he was very isolated. He was a very isolated child. He did not like kisses or hugs... He did not make eye contact, at all. [...] He did not interact, or play, he only cried and screamed (M8).

These data support some studies that indicate that the family plays an important role in the early detection of childhood autism in terms of detecting delayed speaking and language, the absence of interaction with other children of the same age and a preference for social isolation ${ }^{(8,15)}$. Information obtained from the parents helped with the diagnostic hypothesis ${ }^{(6)}$ and early detection, and should therefore be considered.

A case study with blogs on autism revealed that some mothers start to perceive changes in the behaviour and/ 
or development of their children when they start attending preschool or day-care centres. This period marks the start of their search for healthcare professionals, physicians, nurses, psychologists and other therapists until the diagnosis is confirmed ${ }^{(7)}$. This was experienced by some participants of this study, who stated they perceived changes when their children attended preschool, where they could observe the behaviour and development of other children or through the observations of educators.

Participants stated they perceived unusual movements in their children that are common in children with autism, such as flapping of the hands and repetitive back and forth rocking of the body.

When he started sitting, at around four or five months, [...] he started rocking backwards and forwards. [...] I noticed some differences, that he was not like the other children. When he was three and a half, we were really concerned because he did not talk (M1).

I noticed he did not talk [...]. He is just starting to talk [at four]. He did not play with children, he does not look at people [...]. That hand movement, flapping [...] (M3).

I realized she rocked back and forth. She did not speak. She would just scream, she shouted when we would go out for a walk (M6).

Another change perceived by the mothers, which is characteristic of children with autism, was an attraction for objects with rotational movements, such as car wheels and fans, as stated by M3, M4 and M7:

He would always turn the lid of the microwave oven a lot [...], car wheels (M3).

I realized [...] that she was not developing normally [...]. She had this thing with turning. She [...] turned her eyes and would turn them constantly [...]. Sometimes [...] I could not go out with her to public places because she cried; she cried all the time. [...] She was [...] two years old and did not speak! To this day [11 years], she does not speak (M4).

He would spin the car and turn the wheels. Someone gave him a fan [...] and he would put it close to his cot and it was just the fan and him. Everything that rotated interested him. He did not play with other children, there were children who would come and play with him, with my other children, and he would leave, he did not stay (M7).
Some mothers reported that they perceived changes based on the embarrassing behaviour of their children, such as extreme difficulty in interacting with others and excessive irritability.

Someone would come over and he would run and hide under the bed and cry. I would have to tell the person to leave. His godparents, then... He hated them (M9).

She [daughter] has always had these rage attacks (M10).

The signs and symptoms of childhood autism are described in literature as impairments in several developmental areas, especially social interaction, verbal communication, delayed or absent use of language and restrictive, repetitive and stereotyped behaviour and interests ${ }^{(15)}$. However, according to statements of the study participants, these characteristics are very subjective and vary from child to child. The fact that clinical signs and seriousness can vary supports the importance of multi-professional assistance when establishing the diagnosis of childhood autism ${ }^{(15,17-8)}$.

\section{Trajectories of mothers in search of a diagnosis for their children}

In general, the interviewees reported that their trajectories in search of a diagnosis for their children started when they perceived changes in their children's behaviour and/or development. These mothers went through several services and healthcare professionals until the medical diagnosis was obtained, as stated below:

I went to the paediatrician and he asked for several evaluations. He asked for an evaluation from the doctor, and speech therapist, the physical therapist... And then I had to take him here and there. In spite of everything, I still did not have a diagnosis. [...] a child neurologist [...] said that she [the child] had global developmental delay. [...] I actually only found out last year [when the child was seven] (M10).

I went to the paediatrician and she said, "You're right, she doesn't speak!" Two years old and she didn't say a word [...]. Then she referred me to a neurologist, who asked for lots of tests [...], thinking she [the child] was deaf. [...] The neurologist sent me to a speech therapist, who did nothing and sent me to a psychiatrist. I went back to the neurologist, who said, "[...] There is nothing wrong with her. [...] I think its global developmental delay [...]" (M5). 
The neurologist asked for hearing tests, to see if he was deaf. [...] The speech therapist mentioned autism, saying: "Maybe it's autism, he doesn't speak and all..." She started to ask me lots of questions, and they all fit with autism. [...] The nurses, you know, [...] those kids that cry and that? They realized he was difficult, but I think they thought he was a weird, spoilt child (M9).

Children with autism generally present different characteristics to those of other children, such as impaired communication skills and behaviour ${ }^{(2)}$. These characteristics, however, may be appear in a bland and subjective manner.

Most mothers of children with autism initiated their trajectory in search of answers to the alterations perceived in their children in primary care, which is the access point of the SUS. However, participants of this study reported that healthcare professionals did not perceive changes in their children's behaviour or development, which hindered early diagnosis.

Not even the doctors knew, the doctors said she was normal (M2).

At the health unit [...] no one [healthcare professionals] said anything, and she [child] was already a year and a half (M4).

They never noticed anything [...]. As he didn't do anything in particular, they [nursing technicians] said some children start talking at the age of six, seven (M8).

The participant's statements also showed that after perceiving changes in the behaviour and/or development of their children or after being oriented by child educators, the mothers initiated an arduous trajectory of healthcare service utilization in search of an answer. The childhood autism diagnosis is provided by a multi-professional team of nurses, psychologists, physicians, speech therapists, physical therapists, psychopedagogists, and others. These professionals evaluate the behaviour and development of the child, and conduct laboratory and imagery tests to discard other diseases ${ }^{(15)}$

One mother stated that the changes in her son were not too visible for the healthcare professionals. Initially, only those who lived with the child perceived uncommon characteristics and developmental changes were only observed as the child got older.

At first I had a [health] plan, then I went to a medical unit and they [nurses] never noticed [changes in the child].
Only those who lived with him noticed any differences. It increased [...], we noticed, as he got older (M1).

In this perspective, a mother (M7) reported that nurses that already knew the child, due to greater contact after routine consultations, mentioned that the child had autism. However, a medical diagnosis had not yet been confirmed.

Several nurses said during routine consultations, "I think your son is autistic". They knew him and said, "It's autism!" [...] The neurologist only said that he [child] had mental retardation. [...] I needed the ICD [International Classification of Diseases] and the neurologist stated that it was mental retardation. And l asked, "What type of retardation does he have?" "His development is delayed one year," the neurologist said (M7).

One participant reported that the search of a diagnosis for her son started after the evaluation of a psychopedagogist at the preschool that her son attended:

I've always worked and he would go to preschool. One day the owner of the school said, "I asked the psychopedagogist to spend the day with your son. No offense, ok? She just wants to talk to you in her consultation room". Then she [psychopedagogist]talked to me about autism, she explained, asked me lots of questions and asked me not to hide anything because most parents hide things. [...] She told me what autism was and referred me to doctors. I went on a health service pilgrimage! (M3).

Evidently, child educators should be prepared when confronted with signs and symptoms that suggest childhood autism in order to help the parents and families ${ }^{(16)}$ and refer children to other professionals for a diagnosis.

Early diagnosis is extremely important, as it allows treatment that, despite not contemplating a cure, can significantly improve the child's development and independence ${ }^{(15,17)}$. The statements, however, showed that it is not always east to detect signs and symptoms that are characteristic of autism, which hinders early detection. These data corroborate other studies that emphasize that this difficulty is related to the large number of characteristics that determine childhood autism in children, to the seriousness of the disorder and to the fact that many of these children have adequate motor development ${ }^{(15,17-18)}$.

Participants of this study stated that their children used the medical and nursing health services offered by 
the UBS. In relation to primary care, they stated the nurses were frequently responsible, together with a paediatrician, for the child's routine healthcare. Therefore, these professionals should be capable of detecting the symptoms of childhood autism at the early stages. This would allow direct action, the creation of a care plan and referral of the child to specific professionals to confirm diagnosis and initiate treatment ${ }^{(15)}$. Consequently, researchers ${ }^{(19-20)}$ emphasize that nurses must be trained to provide support in case of investigation, suspicion or confirmation of a diagnosis of childhood autism.

Nurses can help elucidate the diagnosis through behavioural observation of the child during nursing consultations and by acting as a healthcare educator, which would support the search of a diagnosis ${ }^{(15,19)}$. Nurses can focus on providing care for the child and family, listen and consider their observations, share knowledge on autism, evaluate the family's level of understanding on the disorder and help them face the new reality.

\section{FINAL CONSIDERATIONS}

This study provided an understanding of the perceptions of mothers of children with autism on the behavioural and/or developmental alterations of their children. It showed that, in general, early diagnosis does not occur, but mothers detect the first signs and symptoms that are characteristic of autism in their children and subsequently seek medical assistance that can elucidate a diagnosis and provide treatment for their children.

Results indicated that these mothers face difficulties in the trajectories they must complete in search of a diagnosis for their children. They embark on an arduous course through the healthcare services, consult with several professionals and, in many cases, receive a late diagnosis. Consequently, it is important for professionals to consider maternal perceptions on the growth and development of children, which can favour early diagnoses.

Considering the obtained results, this study can support nursing practices, as it reveals the importance of training nurses to better assist children with autism and their family members during the nursing consultation and during permanent team training.

Additional nursing investigations should be conducted on this topic using different research methods and other data collections strategies that would help to understand the particularities of this population. Further awareness and training for professionals involved in child care would support effective evaluations and accompaniment of childhood behaviour and development, as well as qualified assistance that considers the needs of these children and their families.

\section{REFERENCES}

1. Ministério da Saúde (BR). Saúde mental no SUS: acesso ao tratamento e mudança do modelo de atenção. Brasília; 2007.

2. Associação Americana de Psiquiatria. DSM-V: manual e diagnóstico e estatístico de transtornos mentais. 5. ed. Porto Alegre: Artmed; 2013.

3. Ministério da Saúde (BR). Caminhos para uma política de saúde mental infanto-juvenil. Brasília; 2005.

4. Lopez-Pison J, Garcia-Jimenez MC, Monge-Galindo L, Lafuente-Hidalgo M, Perez-Delgado R, Garcia-Oguiza A, et al. Our experience with the a etiological diagnosis of global developmental delay and intellectual disability: 2006-2010. Neurologia. 2014;29(7):402-7.

5. Volkmar FR, MCPartland JC. From Kanner to DSM-5: autism as an evolving diagnostic concept. Annu Rev Clin Psychol. 2014;10:193-212.

6. Machineski GG, Schneider JF, Camatta MW. 0 tipo vivido de familiares de usuários de um centro de atenção psicossocial infantil. Rev Gaúcha Enferm. 2013;34(1):126-32.

7. Montardo SP, Passerino LM. Implicações de redes temáticas em blogs na Análise de Redes Sociais (ARS): estudo de caso de blogs sobre autismo e síndrome de Asperger. Interface Comun Saúde Educ. 2010;14(35):921-30.

8. Favero-Nunes MA, Santos MA. Itinerário terapêutico percorrido por mães de crianças com transtorno autístico. Psicol Reflex Crit. 2010;23(2):20821.

9. Polit DF, Beck C. T. Fundamentos de pesquisa em enfermagem: avaliação de evidências para a prática da enfermagem. 7. ed. Porto Alegre: Artmed; 2011.

10. Ebert M, Lorenzini E, Silva EF. Trajetórias percorridas por mães de crianças com transtorno autístico. Biblioteca Lascasas. 2013;9(3):1-21.

11. Fontanella BJB, Luchesi BM, Saidel MGB, Ricas J, Turato ER, Melo DG. Amostragem em pesquisas qualitativas: proposta de procedimentos para constatar saturação teórica. Cad Saúde Pública. 2011;27(2):389-94.

12. Bardin L. Análise de conteúdo. 5. ed. Lisboa: Edições 70; 2009.

13. Ministério da Saúde (BR), Conselho Nacional de Saúde. Resolução nº 466, de 12 de dezembro de 2012. Diretrizes e normas regulamentadoras de pesquisas envolvendo seres humanos. Diário Oficial da União [da] República Federativa do Brasil. 2013 jun 13;150(112 Seção 1):59-62.

14. Luza AR, Cecchetto FH, Silva EF. Feelings and difficulties by mothers of children with special needs. Rev Enferm UFPE On Line [Internet]. 2011 [citado 2013 maio 15]; 5(6):1397-402. Available in: http://www.revista.ufpe.br/revistaenfermagem/index.php/revista/article/viewArticle/1636

15. Nunes SC, Souza TZ, Giunco CT. Autismo: conhecimento da equipe de enfermagem. Cuid'Arte Enferm [Internet]. 2009 [citado 2012 jul 28];3(2):13441. Available in: http://www.fundacaopadrealbino.org.br/facfipa/ner/pdf/ ed05enfpsite.pdf

16. Camargo SPH, Bosa CA. Competência social, inclusão escolar e autismo: um estudo de caso comparativo. Psicol Teor Pesqui. 2012;28(3):315-24.

17. Menegoli EB, Mendonça I, Giunco CT. Capacitação de agentes comunitários de saúde sobre 0 espectro autista. Cuid'Arte Enferm [Internet]. 2010 [citado 2012 jul 30];2(1):7-11. Available in: http://www.fundacaopadrealbino.org.br/ facfipa/ner/pdf/CuidArte\%20Enfermagem\%20v.\%204\%20n.\%201\%20jan. jun.\%202010.pdf 
18. Muñoz NB, Parra YP, López MA, Ruiz ACM, Fajardo AG. Niños con trastorno del espectro autista: intervención precoz. Paraninfo Digital [Internet]. 2011 [citado 2013 maio 07];5(11). Available in: http://www.index-f.com/para/n11-12/022p.php

19. Lutz HR, Patterson BJ, Klein J.Coping with autism: a journey toward adaptation. J Pediatr Nurs. 2012;27(3):206-13.
20. Sena RCF, Sobreira MVS. Design and knowledge of nurse the strategies for family health about childhood autism. Rev Enferm UFPE On Line [Internet]. 2012 [citado 2013 mai 15];6(4):969-72. Available in: http://www. revista.ufpe.br/revistaenfermagem/index.php/revista/article/download/2609/3577

\section{Author's address:}

Eveline Franco da Silva

Rua Alexandre Fleming, 454, Madureira

95041-520, Caxias do Sul, RS

E-mail: evelinefranco@yahoo.com.br
Received: 19.11.2013

Approved: 10.11.2014 